\title{
NEWS
}

\section{Health Canada lukewarm on Vioxx panel findings}

An expert panel is recommending the reintroduction of rofecoxib (Vioxx) on the Canadian market, but Health Canada is unsure about some of the panel's evidence and won't make a decision until fall.

Rofecoxib, a COX-2

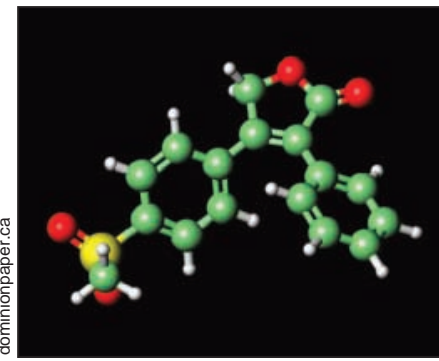

The rofecoxib molecule. findings for patients on NSAIDs." Berthiaume says Health Canada hasn't taken an official position on the study.

In defence of his study, Baigent, a senior scientist at the Clinical Trials Service Unit at Oxford University, says that "ideally we'd like individual patient data ... . When you've only got tabular results you can only group the short-term and long-term studies together." $\mathrm{He}$ adds, "What we desperately need is to have the data publically available." The study is being considered for publication in a peer-reviewed journal.

The expert panel chair, Dr. Andreas Laupacis, said the paper is "one of the highest quality of systematic reviews we've seen." Dr. Claire Bombardier, lead author on the Vioxx Gastrointestinal Outcomes Research (VIGOR) study, hasn't seen the whole study but says it offers "strong evidence and a balanced view."

If the panel is correct, was Merck's decision to withdraw rofecoxib premature? Berthiaume doesn't think so. "Their decision was based on the safety information available and it was a good decision," he says. Merck
Frosst Canada spokesperson Marlene Gauthier agrees: "At the time there seemed to be alternatives that had less risks."

Reintroducing rofecoxib to the market now depends on Merck Frosst's willingness to resubmit the drug for approval and on Health Canada's approval, which could take 2-18 months.

Some patients are clamouring for the drug to be reintroduced, says Bombardier. Laupacis concurs: "Rheumatologists find some people respond to some drugs and not the others ... they want choice."

While Health Canada debates what to do about rofecoxib, legal proceedings are going ahead, says lawyer Tony Merchant of Regent-based Merchant Law Group. At least 7 suits have been filed, including a 7-province action filed in the Federal Court of Canada naming the federal government as co-defendant.

Merchant believes that the failure to disclose and label rofecoxib properly was the equivalent of failure of informed consent for patients involved.

Merck plans to defend itself on a case-by-case basis. - Sally Murray, CMAJ

\section{DISARMAMENT}

\section{Countries continue to ratify land mines treaty}

In July, Latvia became the 145th country to become bound to the Ottawa Convention, an international treaty to ban anti-personnel land mines first signed by 122 countries in Ottawa in December 1997.

The Convention on the Probibition of the Use, Stockpiling, Production and Transfer of AntiPersonnel Mines and on their 을 Destruction prohibits the manufacture, trade and use of antipersonnel mines; obliges countries to destroy stockpiles within ô 4 years and to clear their territory of land mines within 10 years; and urges governments to help poorer countries clear land and rehabilitate survivors.

The US, Russia and China are among those who have not signed. Russia and China argue that land mines are necessary to protect their borders. The US voted in favour of UN resolutions supporting the treaty's implementation, but is focused on researching alternatives, including land mines that self-destruct after a specified period.

The World Association for Disaster and Emergency Medicine (WADEM) reiterated its support for the treaty at its conference in May and resolved to continue monitoring progress.

Land mines still kill, blind or maim an estimated 20000 30000 people annually.

However, Rodney Moore at Canada's Department of Foreign Affairs, the lead government agency on the treaty, says "Victim rates are significantly down, valuable land is being returned to productive use [and] there is no trade in these weapons."

The treaty was open for signature until it came into force with the 40th ratification in March 1999. States may now become bound by a one-step process called accession. Of the world's 194 states, 41 have not signed or acceded; 8 signatures are unratified.-Pauline Comeau, Ottawa 